\title{
Numerical thermal analysis of the vertical external partition made as the frame thin-walled steel structure
}

\author{
Maciej Major ${ }^{1, *}$ and Mariusz Kosin $^{1}$ \\ ${ }^{1}$ Technical Sciences, Department of Steel Constructions and Building Materials, Faculty of Civil \\ Engineering, Częstochowa University of Technology, 42-200 Częstochowa, Poland \\ 2 Technical Sciences, Department of Organization and Building Technology, Faculty of Civil \\ Engineering, Częstochowa University of Technology, 42-200 Częstochowa, Poland
}

\begin{abstract}
The article presents numerical thermal analysis of the vertical external partitions made in the lightweight steel framing technology. Steel posts that perform the structural role lead to the formation of linear thermal bridges and have a negative effect on the level of thermal transmittance $U$. Therefore, optimal solutions are being explored for such technologies. One of the solutions is to use perforated Thermo sections. The effect of perforated Thermo sections on energy loss was verified through comparison to the wall made of solid sections. Furthermore, the calculations analysed the effect of linear thermal bridges that are formed on wall connections in the corner. Computer simulation was employed to emphasize the significant differences in the temperature distribution in both analysed wall structures that resulted from constructional solutions.
\end{abstract}

\section{Introduction}

The problems concerning energy loss for the external walls in buildings continue to be particularly important as they affect maintenance costs in the heating season. The use of modern technologies based on framing structures made of cold-rolled steel sections that have been widely used in building structures (see [2]) substantially reduces the time to complete the investment (construction of a building), but the analysis of this structure from the standpoint of building's physics is needed. In order to evaluate heat flux density and temperature distribution in such walls, it is justified to use numerical software based on finite element method (MES) [3-5].

The aim of the study was to develop and compare characteristics of heat protection offered by the external wall, temperature distribution and value of heat loss through heat transfer from the heated space (residential room) to the environment through the wall made using the technology of a light steel framing. The corners of the vertical wall made of two thin-wall sections were analysed for three values of insulation thickness. Based on [6], the internal temperature was adopted as $\Theta_{i}=+20^{\circ} \mathrm{C}$ whereas based on [7], the external

\footnotetext{
* Corresponding author: mmajor@bud.pcz.czest.pl
} 
temperature was adopted as $\Theta_{e}=-20^{\circ} \mathrm{C}$. For these assumptions, two variants of the geometrical solution for the wall corners were compared.

\section{Characterization of walls adopted for thermal analysis}

Six-layer walls were adopted for the analysis, with their load-bearing components showing different structures (Fig. 1). The C-shaped section was adopted in all the cases, with the cross dimensions: $h=140 \mathrm{~mm}, b=38 \mathrm{~mm}, c=18 \mathrm{~mm}, t=1.5 \mathrm{~mm}$ and $r=3 \mathrm{~mm}$.

a)

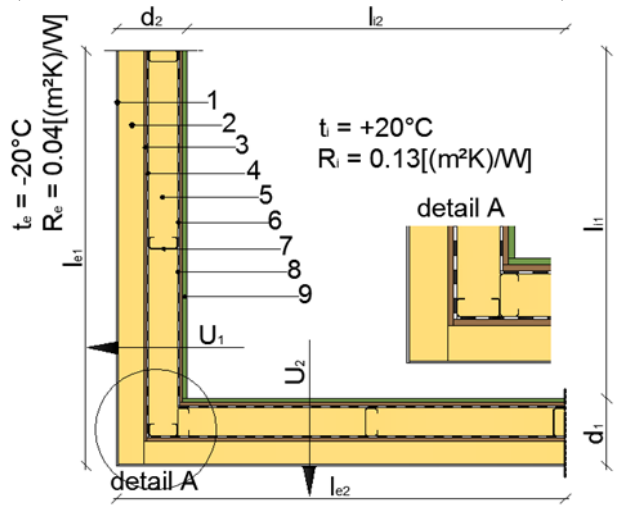

b)

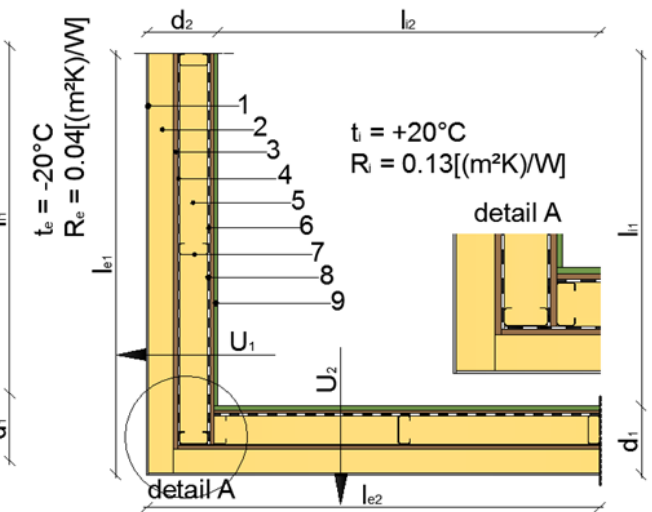

Fig. 1. Computational model for the analysed wall made using the technology of a lightweight steel framing; a) Variant I; b) Variant II; for the corner's solution. 1 - thin-layer plaster, thk. $0.5 \mathrm{~cm} ; 2$ mineral wool, thk. $16 \mathrm{~cm} / 8 \mathrm{~cm} / 5 \mathrm{~cm} ; 3$ - cement-bonded particleboard, thk. $1.2 \mathrm{~cm} ; 4$-vaporpermeable membrane; 5 - mineral wool, $14 \mathrm{~cm} ; 6$ - steel profile C140, thk. $0.15 \mathrm{~cm} ; 7$-vapor barrier; 8 - cement-bonded particleboard, thk. $1.2 \mathrm{~cm} ; 9$ - gypsum plasterboard, thk. $1.25 \mathrm{~cm}$.

\section{Heat parameters of the analysed walls}

The material characterization for the analysed solutions of the corners of the external wall is presented in Table 1. Using the algorithm below through computer simulation, the thermal transmittance $U$ was evaluated for the analysed solutions of the walls [8]:

- calculation of the value of the mean horizontal component of heat flux density for the part of joint $\mathrm{q}_{1}$ and $\mathrm{q}_{2}$,

- calculation of the thermal transmittance based on:

$$
\begin{array}{ll}
U_{1}=q_{1} /\left(\Theta_{\mathrm{i}}-\Theta_{\mathrm{e}}\right) & {\left[\mathrm{W} /\left(\mathrm{m}^{2} \mathrm{~K}\right)\right]} \\
U_{2}=q_{2} /\left(\Theta_{\mathrm{i}}-\Theta_{\mathrm{e}}\right) & {\left[\mathrm{W} /\left(\mathrm{m}^{2} \mathrm{~K}\right)\right]}
\end{array}
$$

An analytical method was used to verify the values of thermal transmittance. The greatest difference in the analytically and numerically calculated thermal transmittance $U$ was $6 \%$. It was assumed for the linear thermal transmittance $\Psi$ that the height of the corner is $1 \mathrm{~m}$. Therefore, after calculation of the linear thermal transmittance, its value can be multiplied by the bridge's length [9].

Heat flux $\Phi$ for the heat flowing through the joint for each variant was calculated using numerical methods, see Table 2 . Table 3 presents heat parameters of the analysed walls.

Numerical calculations showed that thermal transmittance for Thermo sections was higher than thermal transmittance for solid sections. The difference between $U$ values reaches up to $15 \%$. In light of the holes with small surface in a perforated section and the 
simplified grid of finite components in the numerical model, it can be presumed that building a more complex grid would reduce this difference.

Table 1. Material data for analyzed partitions.

\begin{tabular}{|c|l|c|c|}
\hline Ordinal & \multicolumn{1}{|c|}{ Type of material } & $\begin{array}{c}\text { Thickness } \\
\boldsymbol{d}[\mathbf{m}]\end{array}$ & $\begin{array}{c}\text { Thermal conductivity } \\
\lambda[\mathbf{W} /(\mathbf{m} \cdot \mathbf{K})]\end{array}$ \\
\hline 1 & Thin-layer plaster & 0.0045 & 0.7 \\
\hline 2 & Mineral wool & $0.16 ; 0.08 ; 0.05$ & 0.035 \\
\hline 3 & Cement-bonded particleboard & 0.012 & 0.215 \\
\hline 4 & Vapor-permeable membrane & - & - \\
\hline 5 & Steel profile cold formed C140 & 0.14 & 50 \\
\hline 6 & Mineral wool & 0.09 & 0.035 \\
\hline 7 & Vapor barrier & - & - \\
\hline 8 & Cement-bonded particleboard & 0.012 & 0.215 \\
\hline 9 & Gypsum plasterboard & 0.0125 & 0.25 \\
\hline
\end{tabular}

Furthermore, quite different situation is observed for the heat flux $\Phi$ where energy loss through the joint in the form of the wall corner is smaller for the Thermo sections. The same pattern is observed for the linear thermal transmittance $\Psi$. In certain variants, the value of linear thermal transmittance obtained with respect to external dimensions $\Psi_{\mathrm{e}}$ showed an increase, see Table 3.

Table 2. The values of the total heat flux $\Phi$ for the analyzed variants of wall corners.

\begin{tabular}{|c|c|c|c|c|}
\hline \multirow{2}{*}{\multicolumn{2}{|c|}{$\begin{array}{l}\text { Total heat flux } \Phi \text { flowing } \\
\text { through the connector }\end{array}$}} & \multicolumn{3}{|c|}{ Value [W] } \\
\hline & & \multirow{2}{*}{$\begin{array}{c}\mathbf{5} \mathbf{~ c m} \\
28.369\end{array}$} & \multirow{2}{*}{$\frac{\mathbf{8 ~ c m}}{22.903}$} & \multirow{2}{*}{$\frac{16 \mathbf{c m}}{15.485}$} \\
\hline 1 & Variant I $\mathrm{P}^{*}$ & & & \\
\hline 2 & Variant I T* & 27.537 & 22.378 & 15.236 \\
\hline 3 & Variant II P* & 28.626 & 23.104 & 15.547 \\
\hline 4 & Variant II T* & 27.904 & 22.627 & 15.328 \\
\hline
\end{tabular}

a)

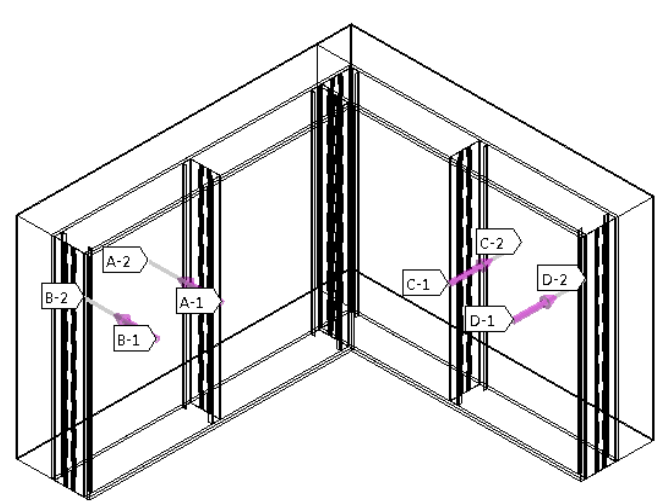

b)

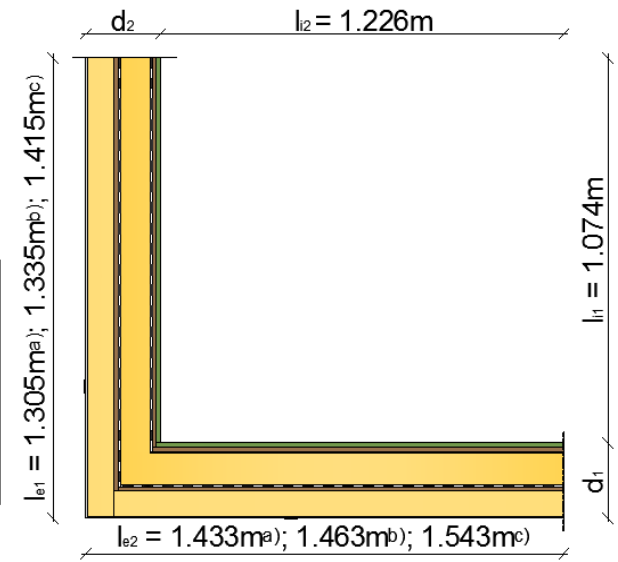

Fig. 2. a) The horizontal "paths" used to determine heat flux density $q\left[\mathrm{~W} / \mathrm{m}^{2}\right]$. b) Dimensions of the wall corners for the analysed insulation thickness: a) $5 \mathrm{~cm} ;{ }^{\text {b) }} 8 \mathrm{~cm},{ }^{\text {c) }} 16 \mathrm{~cm}$. 
The difference between individual values may also result from the horizontal "paths" (see Fig. 2a) in order to calculate heat flux density $q$ and based on equations (1) and (2). Different situation is observed for the heat flux $\Phi$ where the value was calculated for the whole wall.

Table 3. Thermal parameters for analyzed exterior partitions.

\begin{tabular}{|c|c|c|c|c|c|c|}
\hline \multirow{3}{*}{ 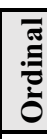 } & \multirow{2}{*}{\multicolumn{3}{|c|}{$\begin{array}{l}\text { The characteristic thermal parameters corner } \\
\text { of the exterior wall }\end{array}$}} & \multirow{2}{*}{\multicolumn{3}{|c|}{$\begin{array}{c}\text { Value } \\
\text { Insulation thickness }\end{array}$}} \\
\hline & & & & & & \\
\hline & \multirow{9}{*}{$\begin{array}{l}\text { The heat transfer coefficient } \\
\qquad U\left[\mathbf{W} /\left(\mathbf{m}^{2} \cdot \mathbf{K}\right)\right] \\
\text { of each part of the connector }\end{array}$} & \multirow{3}{*}{ Variant I $\mathrm{P}^{*}$} & & & & \\
\hline \multirow{8}{*}{1} & & & $U_{1}$ & 0.231 & 0.203 & 0.137 \\
\hline & & & $U_{2}$ & 0.231 & 0.203 & 0.137 \\
\hline & & \multirow{2}{*}{ Variant I T } & $U_{1}$ & 0.237 & 0.211 & 0.144 \\
\hline & & & $U_{2}$ & 0.237 & 0.211 & 0.144 \\
\hline & & \multirow{2}{*}{ Variant II $\mathrm{P}^{*}$} & $U_{1}$ & 0.227 & 0.200 & 0.130 \\
\hline & & & $U_{2}$ & 0.227 & 0.200 & 0.130 \\
\hline & & \multirow{2}{*}{ Variant II T ${ }^{*}$} & $U_{1}$ & 0.232 & 0.212 & 0.144 \\
\hline & & & $U_{2}$ & 0.232 & 0.212 & 0.144 \\
\hline \multirow{4}{*}{2} & \multirow{4}{*}{$\begin{array}{l}\text { Linear coupling coefficient of } \\
\text { thermal } L^{2 \mathrm{D}}[\mathrm{W} /(\mathrm{m} \cdot \mathrm{K})] \\
\qquad \mathrm{L}^{2 \mathrm{D}}=\frac{\Phi}{\mathrm{I} \cdot\left(t_{i}-t_{e}\right)}\end{array}$} & Variant I $\mathrm{P}^{*}$ & $L^{2 \mathrm{D}}$ & 0.709 & 0.573 & 0.387 \\
\hline & & Variant I T* & $L^{2 \mathrm{D}}$ & 0.688 & 0.559 & 0.381 \\
\hline & & Variant II $\mathrm{P}^{*}$ & $L^{2 \mathrm{D}}$ & 0.716 & 0.578 & 0.389 \\
\hline & & Variant II T* & $L^{2 \mathrm{D}}$ & 0.698 & 0.566 & 0.383 \\
\hline \multirow{4}{*}{3} & \multirow{3}{*}{$\begin{array}{c}\text { Linear heat transfer coefficient } \\
\text { (the internal dimensions) } \\
\boldsymbol{\Psi}_{\mathbf{i}}[\mathbf{W} /(\mathbf{m} \cdot \mathbf{K})]\end{array}$} & Variant I $\mathrm{P}^{*}$ & $\Psi_{\mathrm{i}}$ & 0.183 & 0.129 & 0.082 \\
\hline & & Variant I T* & $\Psi_{\mathbf{i}}$ & 0.161 & 0.072 & 0.035 \\
\hline & & Variant II $\mathrm{P}^{*}$ & $\Psi_{\mathrm{i}}$ & 0.211 & 0.126 & 0.094 \\
\hline & $\Psi_{\mathrm{i}}=L^{2 \mathrm{D}}-\left(l_{\mathrm{i} 1} \cdot U_{1}+l_{\mathrm{i} 2} \cdot U_{2}\right)$ & Variant II T ${ }^{*}$ & $\Psi_{\mathbf{i}}$ & 0.172 & 0.043 & 0.042 \\
\hline \multirow{4}{*}{4} & \multirow{4}{*}{$\begin{array}{c}\text { Linear heat transfer coefficient } \\
\text { (the external dimensions) } \\
\boldsymbol{\Psi}_{\mathrm{e}}[\mathbf{W} /(\mathbf{m} \cdot \mathbf{K})]\end{array}$} & Variant I $\mathrm{P}^{*}$ & $\Psi_{\mathrm{e}}$ & 0.082 & 0.034 & -0.006 \\
\hline & & Variant I T* & $\Psi_{\mathrm{e}}$ & 0.045 & -0.034 & -0.065 \\
\hline & & Variant II $\mathrm{P}^{*}$ & $\Psi_{\mathrm{e}}$ & 0.115 & 0.028 & 0.01 \\
\hline & & Variant II T ${ }^{*}$ & $\Psi_{\mathrm{e}}$ & 0.072 & -0.071 & -0.055 \\
\hline
\end{tabular}

$\mathrm{P}^{*}$ - full profile, $\mathrm{T}^{*}$ - THERMO profile

\section{Heat loss through heat transfer}

Heat loss in the building's corner was dimensioned according to the external dimension $l_{\mathrm{e}}$ and external dimensions $l_{i}$ (Fig. 2b). In order to calculate heat loss through heat transfer, the 
calculation of the value of thermal transmittance for the wall with heat bridges $U_{\mathrm{kc}}$ was based on the simplified method [10]. It consists in adoption of the corrected value of thermal transmittance:

$$
U_{k c}=U_{k}+\Delta U_{t b} \quad\left[\mathrm{~W} /\left(\mathrm{m}^{2} \cdot \mathrm{K}\right)\right]
$$

where:

$U_{k c}$ - corrected thermal transmittance of the building component $(k)$ including linear thermal bridges $\left[\mathrm{W} /\left(\mathrm{m}^{2} \cdot \mathrm{K}\right)\right]$;

$U_{k}$ - thermal transmittance for building component $(k),\left[\mathrm{W} /\left(\mathrm{m}^{2} \cdot \mathrm{K}\right)\right]$;

$\Delta U_{t b}$ - correction coefficient depending on the type of building component, $\left[\mathrm{W} /\left(\mathrm{m}^{2} \cdot \mathrm{K}\right)\right]$.

For the calculated corrected thermal transmittance $U_{k c}$ (Table 3) and adopted wall surface area $A=20 \mathrm{~m}^{2}$ the heat loss coefficient $H_{t i}$ was calculated using external dimensions.

$$
\left.H_{t i}=A_{k} \cdot U_{k}[\mathrm{~W} / \mathrm{K})\right]
$$

where:

$A_{k}$ - cross-section of the analysed wall,

$U_{k}$ - corrected thermal transmittance of the building component $(k)$ including linear thermal bridges, $\left[\mathrm{W} /\left(\mathrm{m}^{2} \cdot \mathrm{K}\right)\right]$.

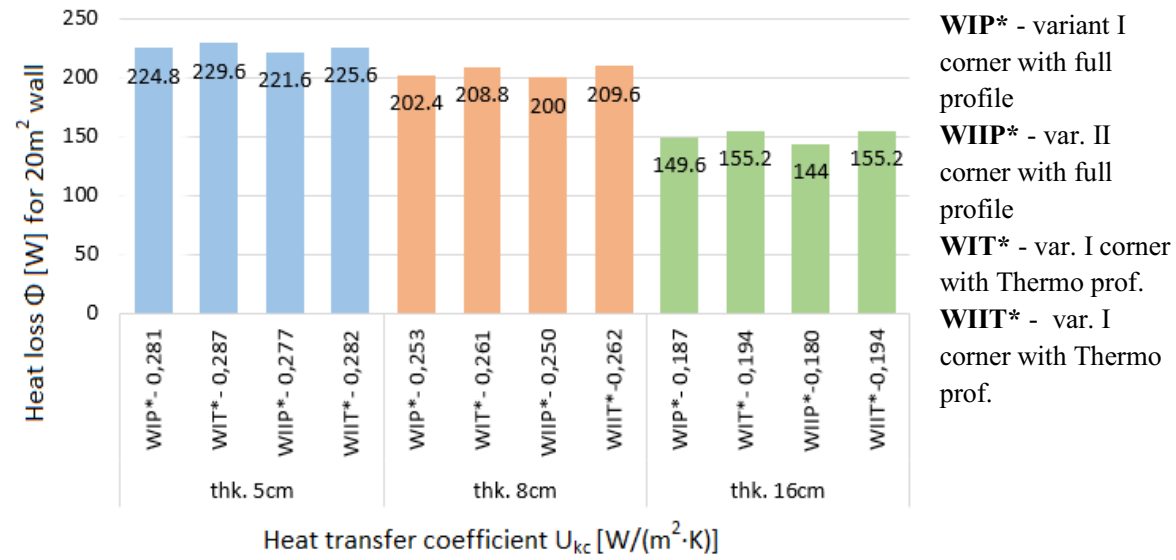

Fig. 3. Heat loss through $20 \mathrm{~m}^{2}$ wall surface in the lightweight framing structure.

Heat loss $\Phi_{t e}$ from the heated space through heat transfer through the wall was calculated according to (5).

$$
\Phi_{t, e}=H_{t, i} \cdot\left(\Theta_{i}-\Theta_{e}\right) \quad[\mathrm{W}]
$$

where:

$H_{t, i}-$ heat loss coefficient, [W/K];

$\Theta_{i}$ - adopted internal temperature $293.15[\mathrm{~K}]$;

$\Theta_{e}$ - adopted external temperature $253.15[\mathrm{~K}]$.

The results of heat loss for the analysed walls were presented in Fig. 4.

\section{The results of numerical analysis}

The numerical thermal analysis was conducted using ANSYS software in the Steady - State Thermal module [11,12]. Tables 4 and 5 show temperature distribution and vector 
distribution of heat flux density for the variants of wall corners. In the walls with $5 \mathrm{~cm}$ and $8 \mathrm{~cm}$ insulation, the heat flux density is transferred to the outside. Different situation is with the insulation with thickness of $16 \mathrm{~cm}$. Furthermore, the temperature distribution at the internal side of the wall corner reveals lower temperature for insulation thickness of 5 and 8 $\mathrm{cm}$. This situation occurs for all the variants of wall corners.

Table 4. The results of computer simulation for the solid section (variants I and II) of the corner solution: temperature distribution and vector distribution of heat flux density.

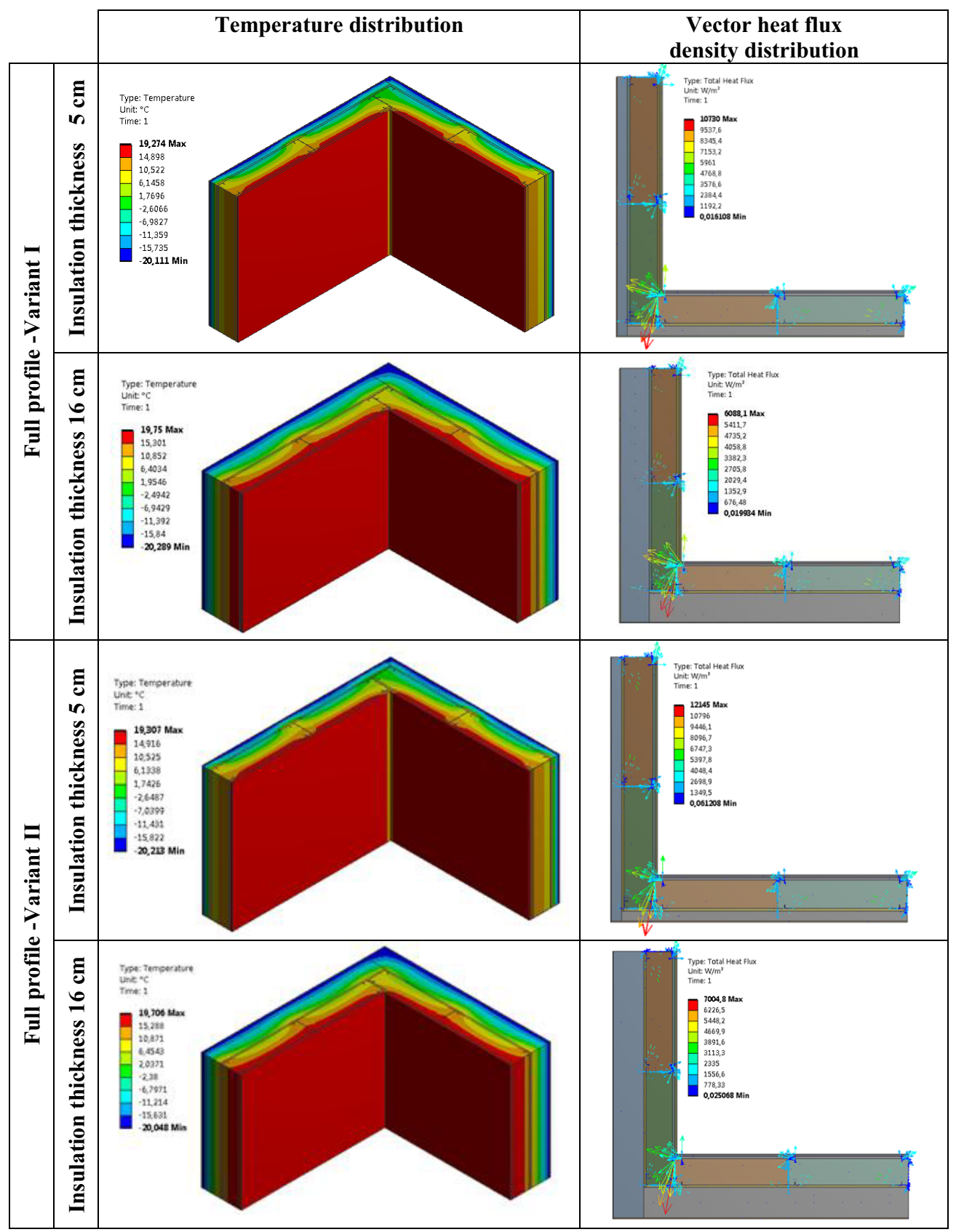


Table 5. The results of computer simulation for the THERMO section (variants I and II) of the corner solution: temperature distribution and vector distribution of heat flux density.

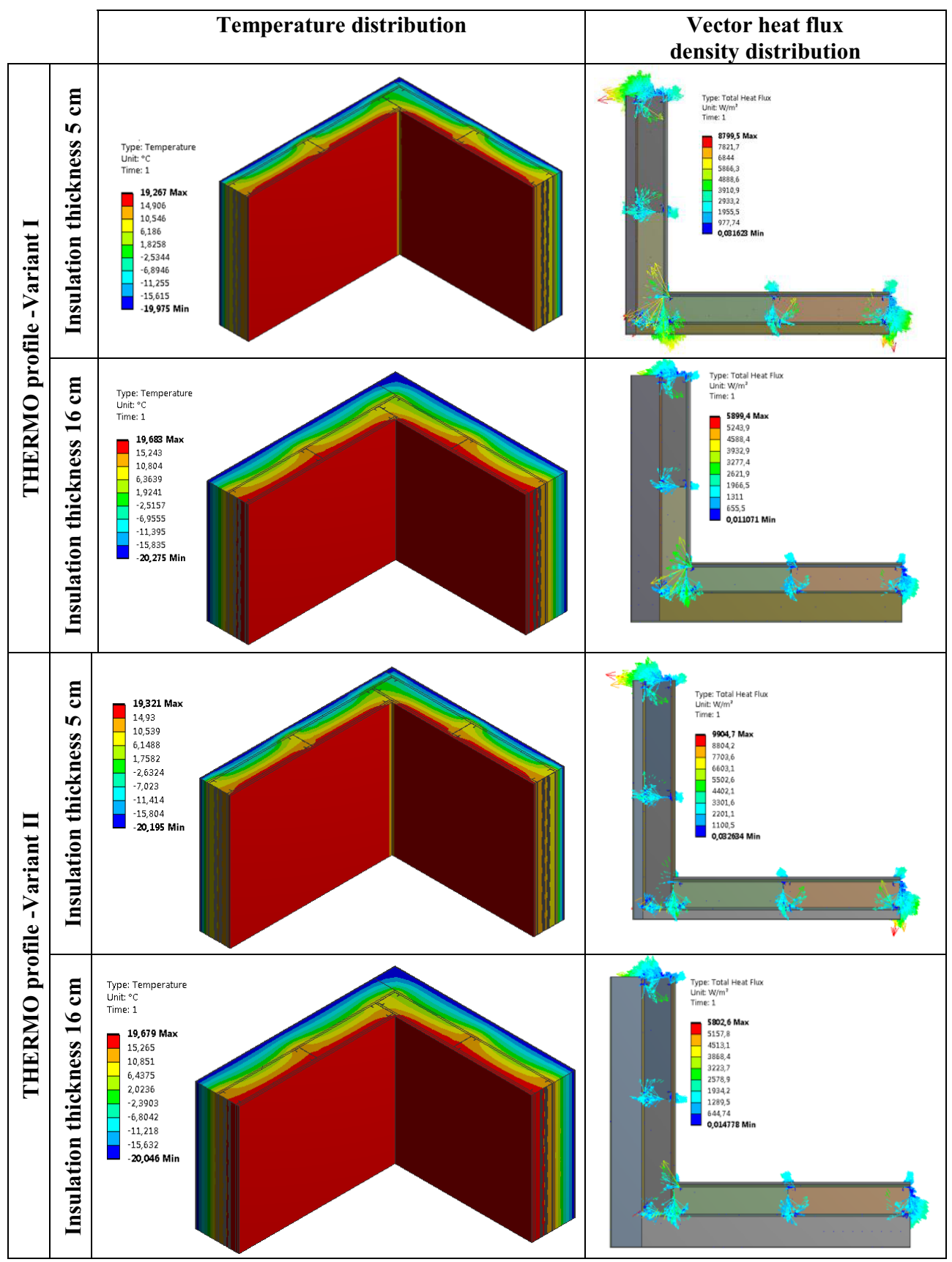

The tables abowe show that the lowest temperature at the internal side is $19.267^{\circ} \mathrm{C}$, calculated for the Thermo section (Variant I). Furthermore, the highest temperature of $19.750^{\circ} \mathrm{C}$ was found for the solid section (Variant I). The biggest difference in the internal temperature between the wall corner variants is around $0.5 \%$. 


\section{Summary}

The study evaluated temperature distribution and energy loss in walls with steel framing structure made of cold-rolled sections. Two types of sections and two variants of geometrical solution were analysed for the wall corner. Tables 2 and 3 contain thermal parameters of the analysed walls. The values of total heat flux $\Phi$ for Thermo sections for the variants analysed in the study is by ca. 3\% smaller compared to solid sections. Furthermore, the difference in the heat loss $\Phi_{\mathrm{t}, \mathrm{e}}$ for the analysed wall is by ca. $5 \%$ greater in solid sections. However, with the simplified method of calculations and adoption of the simplified grid of finite elements, this difference would change, with higher values found for Thermo sections.

The analysis for two different sections did not show significant changes in terms of temperature distribution. The calculations did not reveal a significant effect on the improvement in the thermal insulation properties of the wall through by using Thermo sections.

Numerical computation software based on finite element method (FEM) is useful in analysis of homogeneous structures, such as the framing structure of external walls analysed in this study. With numerical computations, analysis of technological and construction solutions can be made at the design stage, which has a substantial effect on the functional properties of the building. Finding weak points of the wall that are characterized by the most substantial heat loss offers opportunities for the improvement of adopted technological and construction solutions. However, the focus should be on discretization of the analysed geometry.

\section{References}

1. I. Major, Jakościowe i ekologiczne aspekty $w$ technologiach budowlanych, 86-102, In polish (2013)

2. J. Flodr, M. Krejsa, D. Mikolášek, O. Sucharda, L. Žídek, Appl. Mech. Mat. 617, 171174 (2014)

3. B. Balogh, J. Lógó, Transactions of the VŠB - Technical University of Ostrava, Civil Engineering Series, 15, 2 (2016)

4. I. Major, Civil and environmental engineering, Scientific - Technical Journal, 10, 1, 42-48 (2014)

5. M. Major, I. Major, Advanced Materials Research, 1020, 165-170 (2014)

6. Rozporzadzenie Ministra Infrastruktury $z$ dnia 12 kwietnia 2002 r. w sprawie warunków technicznych, jakim powinny odpowiadać budynki i ich usytuowanie, Dz.U. z 2002 r., Nr 75, poz. 690, In polish (2002)

7. PN-EN 12831:2006. Instalacje ogrzewcze w budynkach - Metoda obliczania projektowego obciązenia cieplnego, in polish (2006)

8. A. Gołaś, M. Ryś, Modelowanie Inżynierskie, In polish (2011)

9. BuildDesk, Straty ciepła przez przewodzenie a sposób wymiarowania. PN - EN ISO 10211-1; Materiały edukacyjne dla doradców i audytorów energetycznych, In polish

10. PN-EN ISO 14683:2008, Mostki cieplne w budynkach. Liniowy współczynnik przenikania ciepła. Metody uproszczone i wartości orientacyjne, In polish

11. ANSYS Mechanical APDL Thermal Analysis Guide (2013)

12. E. Madenci, I. Guven, The Finite Element Method and Applications in Engineering Using ANSYS® (Springer, 2007) 